\title{
THE HISTORY OF THE FORMATION AND THE CURRENT STATE OF THE CULTURAL AND HISTORICAL LANDSCAPES OF CENTRAL RUSSIA, THAT ARE UNIQUE OBJECTS OF NATURAL AND CULTURAL HERITAGE
}

DOI: http://dx.doi.org/10.18509/GBP.2019.26

UDC: 911.52:94(470)

\author{
Viacheslav Nizovtsev ${ }^{1}$ \\ Natalia Erman ${ }^{2}$ \\ ${ }^{1}$ Lomonosov Moscow State University, Geographical faculty, Department of Physical \\ Geography and Landscape Science, Moscow, Russia \\ ${ }^{2}$ S.I. Vavilov Institute for the History of Science and Technology of the Russian Academy of \\ Sciences, Russia
}

\begin{abstract}
Long and intensive development of Central Russia led to the anthropogenic transformation of the original landscapes, which led to formation of specific cultural and historical landscapes. Cultural and historical landscape is integral anthropogenic and natural formation, reflecting the specifics ("culture") of nature use and spiritual life of the ethnic group in specific landscape conditions. Many of them can be classified as relict landscapes, whose main "historical" life was in the distant past. Some of these landscapes are currently at a certain stage of museum preservation, for example, cultural and historical landscape "Borodino Field", the palace and park complexes "Tsaritsino" and "Kolomenskoye" in Moscow, the historic centers of ancient Russian cities, and others.
\end{abstract}

Keywords: Landscapes, Central Russia, natural and cultural heritage

\section{INTRODUCTION}

The forming and development of cultural-historical landscapes are obligate result of evolution of society and nature, as well as, man and landscapes during their coherent growth. As a result of the long-time and intensive human activities many features of the landscapes of Central Russia have changed and their structure has become more complicated. Anthropogenic factor of landscape development and transformation joined the natural factors already in the Holocene; and in the last 2000-2500 years its influence became comparable with the latter. During the different historical periods natural landscapes were exposed to various economic impacts: agriculture (from slash-and-burn cultivation to modern industrial agriculture), forestry, industry (extraction of various minerals), water-economy (from watermills to large reservoirs and hydraulic works for drinking and industrial water supply), recreation, transport, etc. [1, 4].

\section{METHODOLOGY AND METHODS}

The methodology of these studies is based on the landscape-ecological-historical and comparative-geographical approaches which combine landscape, ecological and historical-archeological methods of study. It is important to note, that the tasks in view should be solved on both local (key areas) and regional levels, particularly if the territories are characterized by diverse changes of nature management types occurring on the background of natural landscape-climatic changes. 
Therefore the major stage and the element of studies, which are complex both in their objects and methods applied, is a multi-scale mapping at several hierarchical levels (from regional to local) using the GIS-technologies. Landscape maps represent the structure and spatial distribution of present-day and primary natural territorial complexes (NTCs). Maps of nature management and ecological situations show specific features of manlandscape interrelations during different historical periods of time. At the regional level physiographical provinces, areas and landscapes are mapped at the scales of 1:10000001:2500000. The level of an area (scales of 1:50000-100000 is illustrated by a series of maps of Moscow and some particularly typical areas from the point of their landscapes and history (rank of natural territorial complexes - physical-geographical districts and groups of urotschisches). Key areas mapped at the scales of 1:5000 - 1:10000 form the local level (rank of natural territorial complexes - urotschisches and sub-urotschisches). At this level even more detailed maps and sections at the scales of 1:1000 and 1:2000 have been compiled for the territories in immediate proximity of historical or archeological monuments [3].

As a methodical base of research the combination of field methods (landscape, historical, archeological, palaeopedological, historical-geobotanic and other natural-scientific ones) with office studies (analysis of archival, cartographical, aerophotographical and departmental materials, use of GIS-technologies for the analysis and presentation of results) was used. The laboratory research (palinological, radiocarbon, osteological and geochemical analyses) is of particular importance, as well as the compilation of a series of large-scale landscape maps (present-day and reconstructed landscape structure) and maps of nature management for particular time periods on the basis of landscape-edaphic, indicative landscape-geobotanical and landscape-toponymic methods and a method of palaeolandscape and landscape-historical reconstruction [6].

\section{CULTURAL AND HISTORICAL LANDSCAPES}

Cultural and historical landscape is integral anthropogenic and natural formation, reflecting the specifics ("culture") of nature use and spiritual life of the ethnic group in specific landscape conditions. Many of them can be classified as relict landscapes, whose main "historical" life was in the distant past. Some of these landscapes are currently at a certain stage of museum preservation, for example, cultural and historical landscape "Borodino Field", the palace and park complexes "Tsaritsino" and "Kolomenskoye" in Moscow, the historic centers of ancient Russian cities, and others [3].

That means that these are anthropogenic (AL) and cultural (CL) landscapes. They lost anthropogenic management and continue their growth obeying natural logic. Cultural and historical landscapes alongside anthropogenically transformed natural components include artifacts, socio-facts, mentifacts that can serve as a kind of "biographical chronicle" of life of the population in certain landscape conditions in a particular historical period. These facts are evidences of material and spiritual cultural of society.

Four hierarchical levels of the organization of cultural and historical landscapes have been revealed: the cultural and historical region, the cultural and historical landscape, the landscape and historical locality, the landscape and historical complex.

A cultural and historical region is a set of cultural and historical landscapes on a particular area, reflecting the ways of its historical development. A cultural and historical region is saturated with especially valuable natural and historical and cultural objects, reflecting the typical natural environment and traditional culture, which makes them extremely valuable monuments (territories) of the natural and cultural heritage of our country. An 
example is cultural and historical districts of the "Border West of the Moscow Region" or the North Dvina historical waterway. The cultural and historical landscapes of the ancient Russian border cities-fortresses (Tushkov town, Mozhaisk, Vereya, Borisov, Vyshgorod, Luzhesk) form the basis of the cultural-historical district "Border West of the Moscow Region".

Each kind of cultural and historical landscape has its own structural features defined by their inherent set of landscape and historical complexes of the local level (towns, ancient settlements, burial groups, etc.) and natural features of the original indigenous landscape structure. Often, cultural and historic landscape may include a variety of cultural backgrounds that reflect the stages of economic development and spiritual life of the local population $[8,9,10]$.

The presence of different types of artifacts, buried cultivated soils, cultural backgrounds, or even place names provides the possibility to restore the life pictures of settlers in certain historical periods, as well as to reconstruct the anthropogenic changes in the environment corresponding to different types of nature use.

A special role in the formation of cultural and historical landscapes is played by intellectual and cultural values, which can also become an independent component of the landscape [4].

An example of a "multi-layered" cultural and historical landscape is the territory of the Kolomenskoye museum-reserve, located in the south-west of Moscow, on the right bank of the Moscow river. The anthropogenic transformation of these places began already in the Iron Age. In the vicinity of the former village of Dyakovo, on a high hill remaining from of a high valley outwash plain, there are remains of Dyakovo settlement, dating back to the 1st millennium BC. This settlement gave the name to the whole archaeological culture (Fig.1).

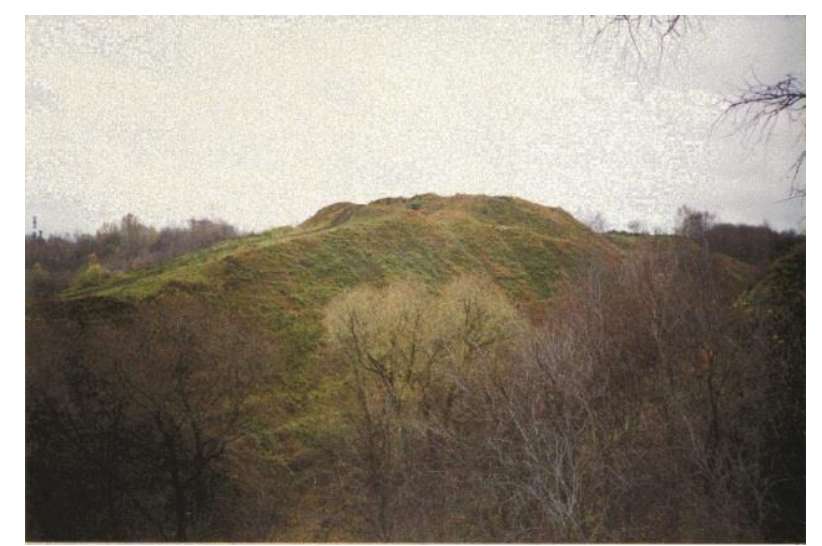

Figure 1. The Dyakovo settlement. Photo V.A. Nizovtsev

The ancient Finno-Ugric tribes of the Dyakovskaya culture are the ancestors of meri and vesi, known from the Russian chronicle sources. Dyakovskaya culture of the Iron Age from the VIII B.C. to VII C.E. occupied the Upper Volga region and almost the entire Volga-Oka interfluve. The village of Kolomenskoye itself has been known since the XIII century. For several centuries, from the XV to XVIII centuries, the royal suburban residence was located here. A part of the royal estate complex (XVI-XVII centuries), the Church of the Ascension (1532), the Church of the Beheading of John the Forerunner in Diakovo (1547), the Church of St. George the Victorious (XVI century) were preserved on the territory of the museum-reserve. The heyday of Kolomna estate fell on the second half of the XVII century. 
Landscape complexes between the interfluves are represented by a combination of flattopped moraine hills, moraine-glacial plains and hollows of glacier water flow. The valley area of this territory occupies relatively small areas and consists of the aboriginal slopes of the washed out bank of the Moscow river, floodplain complexes and small erosion forms. The core of the entire spatial-planning structure is the unique palace and park complex and a masterpiece of architecture of the XVI century - the Church of the Ascension.

In addition, landscape-historical complexes of the main stages of the development of this landscape stand out here. 1) Those of the initial settlement of the territory such as the archaeological monuments of the Neolithic in the floodplain natural and territorial complexes (NTCs). 2) Those of early economic development (Iron Age) such as Dyakovo site of ancient settlement with a system of settlements in valley and outwash plain and floodplain NTCs. 3) Those of the early Middle Ages such as the ancient Russian settlements of the XIII century on outwash plains and moraine-glacial plains. 4) Those of the developed Middle Ages such as elements of the palace household, an orchard, a pond, a Russian village of the XVI century (inter-river near-valley NTCs). 5) Russian village (XIX-XX centuries) with a system of household land in the old agricultural lands.

Landscape and historical locality is characterized by a certain unity of landscape complexes and the processes of their economic development. Their hierarchical level corresponds to the rank of the geographical area. Landscape and historical areas reflect in detail the main ways of settlement and the formation of centres of territorial development of the region. All of them are characterized by a large variety of landscape complexes of the local level, diversity, and sometimes contrast of their properties and respectively, great potential and a rich resource base. This allowed the first settlers to conduct a flexible, complex, interchangeable economy at these sites. For example, the basis of the landscape structure of landscape and historical localities on the territory of Moscow is constituted by landscape complexes of river valleys and outwash plains, constituting single paragenetic complexes.

Landscape-historical complex are the main structural element of cultural-historical landscape and his elementary cell, which forming under influence of natural and manmade factors. Landscape-historical complexes fixed territorial structure of economical activity in determinate time periods. We can re-found the picture of settlers activity in determinate time periods and reconstruct man-made changes in landscape complexes, accompanied with different types of land use. We can do it due to founded artifacts, belowground old land soils, cultural layers and even due to placenames.

The whole set of such complexes now can be considered as the associative category, because material elements in these complexes are absent or dispensable and historicalcultural associations exist in natural elements. Such natural elements are their carriers. For example, belowground old land soils, cultural layers, saturation of different types artifacts in row of landscape complexes. Such carriers may be also placenames, reflected specific land use, mental life in concrete landscape complexes.

The following landscape-historical complexes were identified in Moscow: the landscapehistorical residential complexes (140) - historical settlements, landscape-historical and manor and park (79) complexes, landscape-historical monastery complexes [7]. 


\section{FORMING OF ANTHROPOGENIC AND CULTURAL LANDSCAPES}

Forming of anthropogenic landscapes (AL) links completely with transformation of material and spiritual social life. Appropriately the first AL begin to arise simultaneously with conversation of appropriating economy into generating economy. There was such conversation in Central Russia (Neolithic revolution) only in Bronze Age. In this period the soil become the tools of man's trade.

Forming of first anthropogenic landscapes (AL) and cultural landscapes (CL) is a result of developing of agricultural manufacture, developing of arable farming and pasture economy types, and also a consequence of formation of permanent settlements. The first $\mathrm{AL}$ and CL were connected to features of settlements distribution on territory. Type of arable farming involves to anthropogenic landscape as a subsystem. This subsystem includes functionally conjunct agricultural technology elements, natural attributes of soil and social elements. So we can consider that only anthropogenic modification of natural landscapes have been formed in Mezo-Neolithic stage. Anthropogenic transformed landscape complexes and even man-made landscape complexes have been formed in Bronze Age. Some of these complexes exist now. Actual anthropogenic and cultural landscapes began to form only in Iron Age while permanent, long existed settlement and agriculture structure has organized [5].

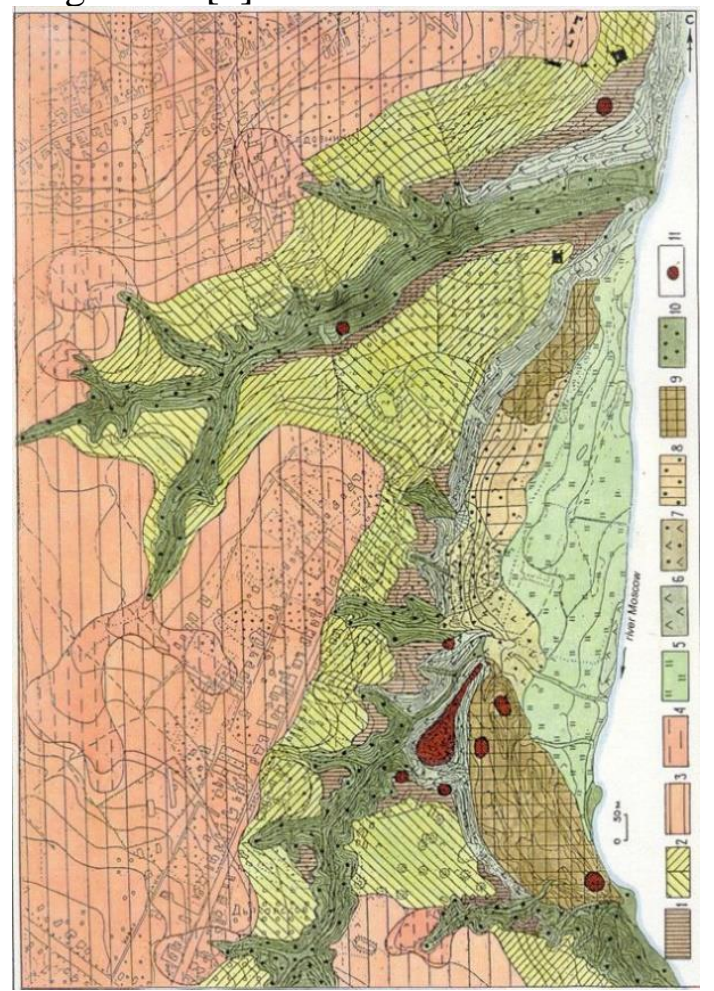

Figure 2. Scheme of nature-use (Iron Age) in the region of "Dyakovo" settlement (natural-economic systems)

1. Arable; 2.Pasture and arable and forest; 3.Forest and pasture and arable; 4. Forestry and Hunting;

5. Pasture and hay; 6. Pasture and meadow; 7. Pasture and forest; 8. Pasture and arable and forest;

9.Pasture and arable and forest10.Forestry and Hunting; 11.Residential (settlements and villages).

Today the numerical preserved landscape-historical complexes are the evidences of these cultural landscapes. Two main kind of anthropogenic landscape complexes has formed in Central Russia in Iron Age. First, These are small settlement anthropogenic landscape complexes (selischa and gorodischa) with applied permanent miniature arable areas 
(arable agrosystems on the level of facia and podurochische). These complexes located on the capes and on the areas between river banks and banks of streams. Second, these are pasture anthropogenic landscape complexes (on the level of podurochische and urochische), located in flood plain and valley-cavin position (pasture plod plain meadowforest). The most extensive anthropogenic landscape complexes with slash and burn agriculture have formed at the same time [6].

Formed land use structure was very stable and optimal for that time. This structure existed nearly thousand years in many regions (for example, territory of modern reserved museum "Kolomenskoe" and others). So we can say about forming of cultural landscape complexes (Fig.2, Fig. 3) [2].

The next important stage of formation AL and CL connected with Slavonic colonization of region and with development of arable agriculture of Slavonic settlers (X-XII centures). There were more than 70 fortified settlements (gorodischa) only in Moscow region.

At the same time the first cultural landscapes of cities (Moscow, Mozshaisk, Serpuhov, Dmitrov, Volokolamsk, Zvenigorod, Ruza and others) appeared and developed, as the centers of densely populated region of arable agriculture. Almost all ancient Russian cities located at the ecotone position nearly of the boundaries of two or more landscapes. There are only five places in the modern Moscow region, where the boundaries of three physicogeographical provinces crosses. And all these places have been occupied by ancient Russian cities. These cities are Moscow, Kolomna, Serpuhov, Volokolamsk, Ruza [7].

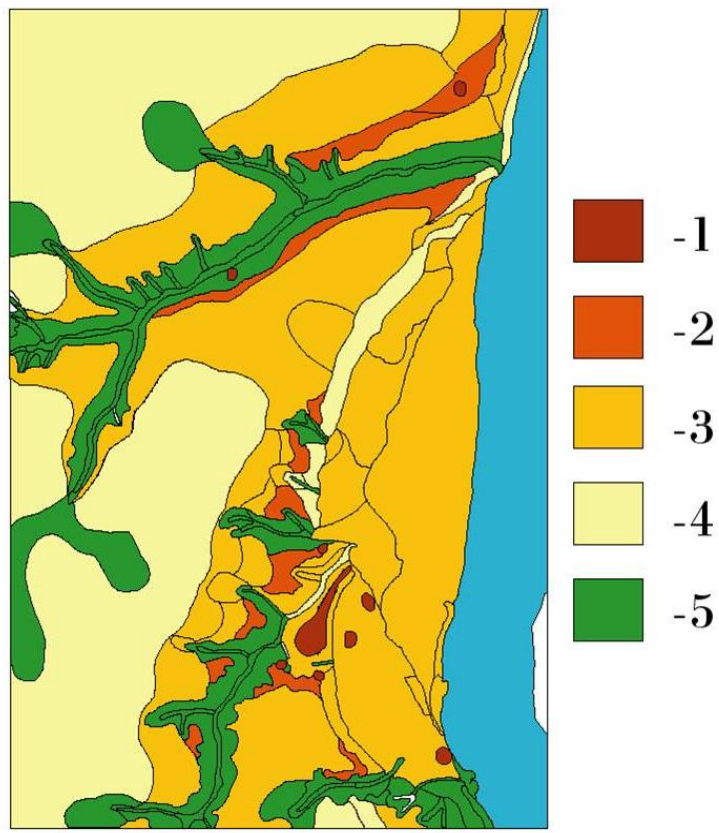

Figure 3. Nature-anthropogenic, anthropogenic and cultural landscape complexes (Iron Age) in the region of "Dyakovo" settlement

1. Cultural landscape complexes; 2. Anthropogenic landscape complexes;

3. Nature-anthropogenic landscape complexes; 4. Anthropogenic modifications of nature territorial complexes; 5. Indigenous and conditionally indigenous nature territorial complexes.

Diversity and contrast of landscape conditions are stipulatory, in the main, by features of lithogenic base and differences of local climate. Moscow cities appeared at the first time on the loamy acclivous valley zandres and terraces. So the areas which surrounded of city, had optimal for arable farming features: plain and drained surfaces, clay-sand fruitful 
soils with advantageous for agriculture air-water regime. These are 'warm" places. Usually soil are ready to use very early in spring at that places.

Spreading of arable farming leaded to localization of permanent places of deep influence on landscape complexes. Unconvertible transformation invaded soils and lithogenous base of landscape complexes, due to pulling and development of erosion processes on the slopes. Excavations of ancient grave-mound on slopes near valleys show us that gravemound have been made on abandoned ploughlands with cultural and often run-off soils. Permanent ploughlands appeared around settlements, which can be considered arable anthropogenic landscape complexes of that time. After that forming of AL connected with internal colonization of region, widely spreading of three-field arable farming and organization of settlement structure on the inerfluves.

The specific arable cultural landscapes complexes appeared in that time: "repischi", "konoplyanniki" (cannabis fields), cabbage crofts, gardens and others. Arable forests become wide-spread anthropogenic complexes. Cleaning and organization of hayfields and pastures were made after termination of planting for preservation and increasing of fertility of soils. Ancient people knew that cultural features of soil preserve better under meadow, then under forest. Complicated melioration procedures were carried out on flood plain: erection of meanders, draining of depressions near by terraces. Different hayfield and pasture cultural landscapes complexes were formed: flood plain type, lowland type, forest type and so on.

The base of modern settlement structure and land use structure have been formed in the majority of Central Russian regions in XIV-XVI centuries. Lea tillage and catch systems with three-fields sowing round and treatment of soil with plough were wide-spread in agriculture. Vast areas of arable cultural landscape complexes were formed. Artificial cultural landscape complexes of upland meadow were appeared. The places for such meadow were organized by slush-burning and removing of brushes and trees.

The quantity of settlements were maximal through all the history of region. There were 20 and more villages for each country-ship. The agricultural limit of mastering of area have been achieved in existed settlement structure. The new type of cultural landscape complexes appeared - artificial ponds on interfluve areas. Monasteries were very active in area mastering. Specific monastery cultural landscape complexes appeared. Anthropogenic landscape complexes appeared of mining ( where limestone can be found) began to formatted [4].

Our investigation showed that anthropogenic and cultural landscape complexes were maximal spread in XVI c. in Central Russia in Middle Age.

\section{CONCLUSION}

We have attempted to develop a classification of landscape and historical complexes and cultural and historical landscapes of Central Russia. The classification is based on the nature and specificity of the relationship between a person and a landscape: first of all, the leading type of human activity at a particular time in a specific landscape conditions. For example, for the Iron Age on the territory of Central Russia, the following types of landscape and historical complexes can be distinguished: 1. Residential; 2. Agriculturepasture-forest; 3. Pasture meadow; 4. Pasture haymaking; 5. Pasture and forest; 6. Forestry; 7. Hunting.

With the development of production capabilities, the relationship between man and nature are becoming more complex and new types of landscape and historical complexes formed. For the Old Russian period, such types expanded: 1. Residential (urban, rural); 
2. Sacred (including necropolis); 3. Arable; 4. Pasture and arable; 5. Pasture-arable-forest; 6. Pasture meadow; 7. Pasture haymaking; 8. Forestry; 9. Hunting; 10. Wild-hive beekeeping; 11. Beaver hunting; 12. Mining.

The following types of cultural and historical landscapes are distinguished on the territory of Central Russia: 1) historical cities, 2) monastic, 3) palace and park, 4) manor, 5) residential (historical rural settlements), 6) rural (historical territories associated with agricultural activities), 7) mining (historical production areas - Pakhra and Myachkovo quarries, etc.), 8) forest and cultural (historical plantations such as Tyurmer, etc.), 9) historical water systems (water reservoirs, for example, Trostenskoe lake, pond systems, canals, etc.), 10) battlefields (for example, the Borodino field), 11) historical ways and roads (for example, the Old Smolensk road).

Therefore, the organic combination of natural and anthropogenic, aesthetic appeal and economic considerations has created altogether a cultural and historical image of the national landscape, formed by the culture of many generations and emphasizing the uniqueness and value of such territories.

\section{ACKNOWLEDGMENT}

The work is performed under the project of Russian Foundation for Basic Research № 19-05-00233

\section{REFERENCES}

[1] Enache C., Craciuna C. The Role of the Landscape in the Identity, Generation Process Procedia - Social and Behavioral Sciences, Romania, vol.92. pp.309-313, 2013.

[2] Gunova V.S., Kirjanova N.A., Krenke N.A., Nizovtsev V.A., Spiridonova E.A. Agriculture in the Moskva river valley in the iron age, Russian archeology, vol. 4, pp.93-120, 1996

[3] Marchenko N.A., Nizovtsev V.A. Complex landscape-ecological study of the territories of historical and cultural heritage, Environmental problems of preservation historical and cultural heritage, Russia, Moscow: Heritage Institute, 2002, pp. 50-66.

[4] Nizovtsev V.A. History of formation of the anthropogenic and cultural landscapes of Central Russia, Proceedings of the XII Congress of the Russian Geographical Society, St. Petersburg, Russia, vol.2. pp. 54-59, 2005.

[5] Nizovtsev V.A. Anthropogenic landscape genesis: the subject and goals of investigations, Vestnik Moskovskogo Unviersiteta, Seriya Geografiya, Russia, vol.1, pp. 26-30, 1999.

[6] Nizovtsev V.A. Toward the theory of anthropogenic landscape genesis, Geography and Natural Resources, Russia, vol. 31, №.2, pp. 95-100, 2010.

[7] Nizovtsev V.A., Erman N.M. Landscape and historical complexes of Moscow, Geology at School and University: Geology and Civilization, Russia, 2015, pp.252-256.

[8] Nikolaev V.A. Cultural landscape - geo-ecological system, Vestnik Moskovskogo Unviersiteta, Seriya Geografiya, Russia, vol. 6., pp. 3-8, 2000.

[9] Taylor K. Cultural landscapes: A bridge between culture and nature, International Journal of Heritage Studies, Australia, vol.17(6), pp. 537-554, 2011.

[10] Tishler W.H. Historical landscapes: an international preservation perspective, Landscape Planning, vol.9(2), pp. 91-103, 1982. 